\title{
PENGARUH PELATIHAN KERJA DAN DISIPLIN KERJA TERHADAP KINERJA KARYAWAN PADA CV. SURYA KENCANA FOOD JOMBANG
}

\author{
Mardi Astutik \\ Jurusan Manajemen STIE PGRI Dewantara Jombang \\ Email: nisa.camelia@yahoo.co.id
}

\begin{abstract}
Job training and discipline is closely related to employee performance improvement in an organization. The better the job training and work discipline, the greater the encouragement of employees to move forward together with the organization. The aim of this study was to examine and explain directly influence job training and work discipline on employee performance. The research method uses quantitative research. Measurement scale used is Likert scale, the population in this study all the production employees CV. Surya Kencana Food Jombang amounted to 280 people, a large sample used as many as 74 people. Penguumpulan engineering data using observations, questionnaires, interviews and documentation. Variables that are rigorous job training and work discipline on employee performance. Data analysis using multiple linear regression analysis with significance level $\alpha=0.05$. The results showed that the job training (X1) has a test statistic $t$ count equal to 2.148 and 0.026 significance, since the value $t$ sig $=0.026$ $<\alpha=0.05$, thus it can be stated that the job training influence on employee performance. Labor discipline (X2) has a test statistic t count equal to 2,243 and signifikani amounted to 0,040 , since the value $\mathrm{t} \operatorname{sig}=0,040<\alpha=0.05$, thus it can be stated that the disciplinary effect on the work performance of employees. These results indicate that job training and work discipline and significant positive effect on employee performance in CV. Surya Kencana Food Jombang
\end{abstract}

Keywords: JobTraining, DisciplineWork,Employee Performance

\begin{abstract}
Abstrak: Tujuan dari penelitian ini adalah untuk menguji dan menjelaskan secara langsung pengaruh pelatihan kerja dan disiplin kerja terhadap kinerja karyawan. Metode penelitian menggunakan penelitian kuantitatif. Skala pengukuran yang digunakan adalah skala likert, populasi dalam penelitian ini semua karyawan bagian produksi CV. Surya Kencana Food Jombang berjumlah 280 orang, besar sampel yang digunakan sebanyak 74 orang. Teknik penguumpulan data menggunakan observasi, angket, wawancara dan dokumentasi. Variabel yang di teliti adalah pelatihan kerja dan disiplin kerja terhadap kinerja karyawan. Analisa data dengan menggunakan analisis regresi linear berganda dengan taraf signifikan $\alpha=0,05$. Hasil penelitian menunjukkan bahwa pelatihan kerja $\left(\mathrm{X}_{1}\right)$ memiliki statistik uji $\mathrm{t}$ hitung sebesar 2,148 dan signifikansi sebesar 0,026, karena nilai $\mathrm{t}$ sig $=$ $0,026<\alpha=0,05$, dengan demikian dapat dinyatakan bahwa pelatihan kerja berpengaruh terhadap kinerja karyawan. Disiplin kerja $\left(\mathrm{X}_{2}\right)$ memiliki statistik uji $\mathrm{t}_{\text {hitung }}$ sebesar 2,243 dan signifikani sebesar 0,040, karena nilai $\mathrm{t}_{\text {sig }}=0,040<\alpha=0,05$, dengan demikian dapat dinyatakan bahwa disiplin kerja berpengaruh terhadap kinerja karyawan.Hasil ini menunjukkan bahwa pelatihan kerja dan disiplin kerja berpengaruh positif dan signifikan terhadap kinerja karyawan pada CV. Surya Kencana Food Jombang.
\end{abstract}

Kata kunci : Pelatihan Kerja, Disiplin Kerja, Kinerja Karyawan 


\section{PENDAHULUAN}

Manajemen adalah ilmu dan seni mengatur proses pemanfaatan sumber daya manusia dan sumber-sumber daya lainnya secara efektif dan efisien untuk mencapai suatu tujuan tertentu. Sedangkan manajemen sumber daya manusia adalah ilmu dan seni mengatur hubungan dan peranan tenaga kerja agar efektif dan efisien membantu terwujudnya tujuan perusahaan,masyarakat, dan karyawan masyarakat. Hasibuan (2007). Selain itu, sumber daya manusia merupakan aset perusahaan yang paling mahal dibanding dengan aset-aset lain karena SDM merupakan penggerak utama organisasi perusahaan. SDM harus dikelola secara optimal, continue dan diberi ekstra perhatianmemenuhi hakhaknya, jadi SDM adalah patner pengusaha untuk mencapai tujuan organisasi. Selain perusahaan, SDM juga senantiasa harus meningkatkan kompetensinya, seiring dengan perkembangan era globalisasi.Ambarita (2012). Agar dapat bersaing dalam persaingan bisnis perusahaan dituntut untuk memperoleh, mengembangkan dan mempertahankan sumber daya manusia yang berkualitas. Sumber daya manusia sebagai penggerak organisasi banyak dipengaruhi oleh para pelaku pesertanya, serta peran fungsinya sangat mendukung untuk keberhasilan organisasi.

CV Surya Kencana Food Jombang merupakan salah satu perusahaan di bidang pengolah makanan produk Gerry food yang hanya didistribusikan ke PT. Garuda Food. Perusahaan ini bukan anak cabang dari PT. Garuda Food melainkan makloon dari PT. Garuda Food, untuk jam kerja dibagian produksi terbagi dalam tiga shift yaitu shift A, shift B, shift C. Karyawan di CV. Surya Kencana Food merupakan karyawan borongan lepas yang proses kerjanya menyesuaikan target mesin yang berjalan terus selama 24 jam proses produksi. Sehingga jika ada salah satu karyawan yang pulang maka harus ada karyawan yang lainnya untuk menggantikannya, jadi untuk proses produksi makanan seperti ini tidak dapat di tinggal sedikit pun sampai target yang di proses oleh mesin-mesin selesai dan karyawan disini harus tepat waktu saat masuk kerja.

Pada perusahaanbentuk pelatihannya sendiri terfokus di sosialisasinya untuk sekarang ini, dengan mengandalkan para trainer dari perusahaan itu sendiri, sebelumnya perusahaan ini ada dua pelatihan yang dimiliki yaitu on the job training dan off the job training. Untuk on the job training para tranernya diambil dari perusahaan sendiri sedangkan off the job training tranernya di datangkan dari lembaga pelatihan yang langsung dari PT. Garuda Food. Pelatihannya disesuaikan dengan bagiannya sendiri seperti salah satu karyawan yang memegang bagian mixer ada pelatihannya tersendiri jadi setiap 7 item alat antara lain mesin, mixer, wcr, ballmill, extruder, packaging, baking csp di perusahaan memiliki pelatihan tersendiri dan ada materi - materi yang disampaikan sebelum pelatihan dimulai, untuk pelatihannya butuh waktu 2 minggu sampai satu bulan saat pelatihan berlangsung, namun bagi karyawan sendiri dalam waktu pelatihan tersebut dirasa kurang cukup.

Dan untuk off the job training itu dilaksanakannya dengan rentan waktu yang cukup lama karena perusahaan ini perlu membutuhkan dana yang cukup untuk pelaksanaan proses pelatihan dari luar. Pelatihan menurut Desller (2009) adalah salah satu usaha dalam meningkatkan mutu sumber daya manusia dalam dunia kerja. Jadi perusahaan tersebut perlu adanya pelatihan khusus dengan mengundang para trainer yang berkualitas sehingga karyawan baik yang baru ataupun yang sudah bekerja perlu mengikuti pelatihan karena adanya tuntutan pekerjaan yang dapat berubah akibat perubahan lingkungan kerja, strategi, dan lain sebagainya. Untuk menyempurnakan hasil akhir suatu pelatihan haruslah diingat 
bahwa proses selama pelatihan itu berlangsung harus jelas di mengerti dan dipahami bagi para peserta pelatihan.

Pelatihan kerja saja tidak cukup, disiplin kerja juga dapat dikatakan sebagai upaya untuk meningkatkan kinerja karyawan di CV Surya Kencana Food. Hetami (2008) mengatakan bahwa sikap disiplin meningkatkan kinerja karyawan dengan mengeluarkan peraturan yang harus dilakukan oleh tiap karyawan dalam rangka agar karyawan tetap dalam koridor aturan yang telah ditetapkan oleh perusahaan dalam usaha pencapaian tujuan perusahaan. Peraturan yang ditetapkan perusahaan diharapkan mampu memupuk kesadaran karyawan untuk lebih disiplin Amran (2009) mengatakan bahwa disiplin mengandung makna proses "latihan yang memperkuat", koreksi dan sanksi", "kendali untuk menciptakan ketertiban dan keteraturan", "sistem aturan tata laku". Disiplin dikaitkan dengan latihan yang memperkuat terutama ditentukan pada pikiran dan watak untuk menghasilkan kendali diri, kebiasaan untuk patuh dan sebagainya.

Pada karyawan dibagian produksi CV. Surya Kencana Food ada aturan dari perusahaan serta aturan yang dibuat oleh ketua shift di bagian produksi itu sendiri, peraturannya jika ada karyawan yang terlambat kerja dikenakan denda sekitar antara Rp. $25.000,00$ - 30.000 dan uang denda itu masuk ke kas bagian produksi dan perusahaan tidak ikut campur masalah denda tersebut. Untuk masuk perusahaan ini setiap para karyawan selalu menggunakan seragam yang sudah di tetapkan perusahaan dan sesalu menggunakan kartu pengenal. Disiplin kerja di perusahaan ini terfokus di tepat waktunya untuk masuk kerja dan menyelesaikan pekerjaannya sesuai target yang sudah ditetapkan oleh perusahaan. Dari 280 karyawan produksi ada sekitar 40\% yang telat masuk, sehingga dari masalah itu hasil kerja yang diperoleh kurang maksimal mengakibatkan penurunan kinerja pada karyawan. Jadi dapat disimpulkan bahwa pelatihan dan disiplin kerja di CV. Surya Kencana Food kurang maksimal sehingga mengakibatkan penurunan pada kinerja.

Kinerja dapat diketahui hasil kerja yang dilakukan oleh karyawan, sesuai pendapat dari sinambela (2012) mengungkapkan kinerja pegawai sangatlah perlu, sebab dengan kinerja ini akan diketahui seberapa jauh kemampuan pegawai dalam melaksanakan tugas yang dibebankan kepadanya. Dengan adanya Masyarakat Ekonomi Asean (MEA) saat ini seharusnya CV. Surya Kencana Food lebih memperbaiki lagi sistem pelatihan dan kedisiplinan untuk mempertahankan kualitas perusahaannya karena persaingan yang ketat dan para profesional akan semakin meningkatkan skill, kompetensi serta profesionalitas yang di miliki.

Permasalahan dalam penelitian ini adalah: Adakah pengaruh positif antara pelatihan kerja terhadap kinerja karyawan di CV. Surya Kencana Food; (2) Adakah pengaruh positif antara disiplin kerja terhadap kinerja karyawan di CV. Surya Kencana Food.

Penelitian terdahulu. Penelitian yang dilakukan oleh Leonando Agusta (2013), Sampel penelitian sebanyak 45 orang karyawan yang meliputi seluruh karyawan yang bekerja sebgai operator alat berat. Metode analisis data yang digunakan adalah motode analisis regresi linier berganda.. Hasil penelitian ini menunjukkan bahwa pelatihan berpengaruh positif dan signifikan terhadap kinerja karyawan. Motivasi kerja berpengaruh positif dan signifikan terhadap kinerja karyawan. Sementara variabel pelatihan dan motivasi kerja berpengaruh positif dan signifikan bersama-sama terhadap kinerja karyawan operator alat berat CV. Haragon Surabaya.

Penelitian yang dilakukan oleh Hendri Hestisani (2014), Populasi ini adalah seluruh pegawai Badan Kepegawaian Kabupaten Buleleng yang berjumlah 84 pegawai. Analisis dengan menggunakan analisi jalur. Berdasarkan hasil perhitungan uji statistik path 
analysis menunjukkan bahwa motivasi berprestasi berpengaruh terhadap kinerja pegawai pada Badan Kepegaiwaian Daerah Kabupaten Buleleng Selain pengaruh langsung juga terdapat pengaruh tidak langsung dari motivasi berprestasi terhadap kinerja Berdasarkan perhitugan uji statistik path analysis menunjukkan bahwa disiplin kerja berpengaruh terhadap kinerja pegawai pada Badan Kepegaiwaian Daerah Kabupaten Buleleng

Penelitian yang dilakukan oleh Zahra Idrees (2015),. Sampel telah diambil dari 16 universitas dari kota kembar pakistan yaitu, islamabad dan Rawalpindi Sampel untuk penelitian ini adalah 310. Analisis dengan menggunakan analisis regresi berganda,temuan penelitian menunjukkan bahwa gaji, pelatihan dan motivasi memiliki hubungan positif dengan kinerja kerja tapi gaji memiliki hubungan yang lebih kuat dengan prestasi kerja dari pelatihan dan motivasi. Penelitian ini akan memandu manajer puncak organisasi untuk mendapatkan pemahaman yang baik tentang faktor-faktor yang dapat meningkatkan prestasi kerja karyawan akhirnya akan meningkatkan produktivitas organisasi

Pengertian Pelatihan. Menurut As'ad (2001) pelatihan adalah proses pendidikan jangka pendek yang menggunakan prosedur sistematis dan terorganisasi, yang mana tenaga kerja nonmanajerial mempelajari pengetahuan dan keterampilan teknis untuk tujuan-tujuan tertentu. Pelatihan didefinisikan oleh Ruky (2003) sebagai usaha untuk meningkatkan kinerja karyawan dalam pekerjaannya sekarang atau dalam pekerjaan yang sekarang dilakukan. Pelatihan berorientasi ke masa sekarang dan membantu karyawan untuk menguasai ketrampilan dalam pekerjaannya.

Berdasarkan pengertian di atas dapat disimpulkan bahwa pelatihan kerja pada dasarnya merupakan sebuah proses untuk meningkatkan kompetensi karyawan. Disamping itu, program pelatihan kerja tidaklah memperhitungkan apakah perusahaan berskala besar atau kecil. Pelatihan kerja juga bukan merupakan pemborosan mengingat hasil atau manfaatnya jauh lebih besar daripada biaya atau waktu yang harus disediakan.

Faktor-faktor yang menunjang kearah keberhasilan pelatihan menurut Veithzal Rivai (2004) antara lain: (1) Materi yang dibutuhkan, Materi yang disusun dari estimasi kebutuhantujuan latihan, kebutuhan untuk pengajaran keahlian khusus; (2) Metode pelatihan, yang digunakan melalui metode-metode pelatihan yang secara sistematik;(3) Prinsip pembelajaran, Materi yang digunakan berupa pelatihan yang diberikan; (4) Ketepatan dan kesesuain fasilitas, fasilitas sangat menunjang bagi terlaksananya program pelatihan; (5) Kemampuan peserta pelatihan.

Menurut Carrell dan Kuzmits (1982), tujuan utama pelatihan dapat dibagi menjadi 5 area yaitu: (1) Untuk meningkatkan keterampilan karyawan sesuai dengan perubahan teknologi; (2) Untuk mengurangi waktu belajar bagi karyawan baru agar menjadi kompeten; (3) Untuk membantu masalah operasional; (4) Untuk menyiapkan karyawan dalam promosi; (5) Untuk memberi orientasi karyawan untuk lebih mengenal organisasi.

Pengertian Diplin Kerja. Menurut Singodimedjo (2002) disiplin adalah sikap kesediaan dan kerelaan seseorang untuk mematuhi dan menaati norma-norma peraturan yang berlaku disekitarnya. Disiplin adalah suatu alat yangdigunakan oleh para manajer untuk berkomuniksi dengan karyawan agar mereka bersedia untuk mengubah perilaku serta sebagai suatu upaya untuk meningkatkan kesadaran dan kesediaan seseorang untuk menaati semua peraturan perusahan dan norma-norma sosial yang berlaku. (Rivai, 2004). Disiplin kerja dipengaruhi oleh beberapa faktor (Soejono, 1997): (1) Ketepatan waktu. Para pegawai datang tepat waktu, tertib dan teratur, dengan begitu dapat dikatakan disiplin kerja baik; (2) Menggunakan peralatan kantor dengan baik sikap hati - hati dalam mengggunakan peralatan kantor, dapat menunjukkan bahwa seseorang memiliki disiplin 
kerja yang baik, sehingga peralatan kantor dapat terhondar dari kerusakan; (3) Tanggungjawab yang tinggi. Pegawai yang senantiasa menyelesaikan tugas yang dibebankan kepadanya sesuai dengan prosedur dan bertanggungjawab atas hasil kerja, dapat pula dikatakan hasil kerja yang baik; (4) Ketaatan terhadap aturan kantor pegawai memakai seragam kantor, menggunakan kartu tanda pengenal atau identitas, membuat ijin bila tidak masuk kantor, juga merupakan cerminan dari disiplin yang tinggi.

Pengertian Kinerja. Menurut Mangkunegara (2007) Kinerja adalah hasil kerja secara kualitas dan kuantitas yang dicapai oleh seorang karyawan dalam melaksanakan tugasnya sesuai dengan tanggung jawab yang diberikan kepadanya. Kinerja menurut Hasibuan (2005) adalah suatu hasil kerja yang dicapai seseorang dalam melaksanakan tugas - tugas yang dibebankan kepadanya yang didasarkan atas kecakapan, pengalaman, dan kesungguhan serta waktu. Kinerja merupakan keluaran yang dihasilkan oleh fungsi fungsi atau indikator - indikator suatu pekerjaan dalam waktu tertentu (Wirawan, 2009).

Dharma (2000) tentang pengukuran kinerja dengan cara mempertimbangkan hal hal sebagai berikut: (1) Kualitas yaitu mutu yang dihasilkan dalam pekerjaan (baik atau tidak mutunya). Pengukuran kualitatif keluaran mencerminkan pengukuran "tingkat kepuasan" yaitu seberapa baik penyelesainnya; (2) Kuantitas yaitu jumlah pekerjaan yang harus diselesaikan. Pengukran kuantitatif melibatkan perhitungan keluaran dari proses atau pelaksanaan kegiatan; (3 )Ketepatan waktu yaitu sesuai tidaknya dengan waktu yang direncanakan. Pengukuran ketepatan waktu merupakan jenis khusus dari pengukuran kuantitatif yang menentukan ketepatan waktu penyelesainnya suatu kegiatan.

Langkah - langkah dalam peningkatan kinerja menurut Mangkunegara (2005) sebagai berikut:

a. Mengetahui adanya kekurangan dalam kinerja. Dapat dilakukan memlalui tiga cara, yaitu: (i) Mengidentifikasi masalah melalui data dan informasi yang dikumpulkan terus menerus melalui fungsi - fungsi bisnis; (ii) Mengidentifikasi masalah melalui karyawan;(iii) Memperhatikan masalah yang ada.

b. Mengenal kekurangan dan tingkat keseriusan. Untuk memperbaiki keadaan tersebut, diperlukan beberapa informasi, antara lain: (1) Mengidentifikasi masalah setepat mungkin; (2)Menentukan tingkat keseriusan masalah dengan mempertimbangkan: (i) Harga yang harus dibayar bila tidak ada kegiatan; (ii) Harga yang ahrus dibayar bila adacampur tangan dan penghematan yang diperoleh apabila ada penutupan kekurangan kinerja; (iii) Mengidentifikasikan hal - hal yang mungkin menjadi penyebab kekurangan, baik yang berhubungan dengan sistem maupun yang berhubungan dengan pegawai itu sendiri; (iv) Mengembangkan rencana tindakan untuk menanggulangi penyebab kekurangan tersebut.

Hubungan Pelatihan Kerja Terhadap Kinerja. Pelatihanmerupakan suatu proses pengembangan sumber daya manusia untuk meningkatkan kemampuan intelegensi yang berdampak pada peningkatan kualitas manusia itu sendiri. Pelatihan kerja adalah suatu kegiatan untuk memperbaiki kemampuan kerja karyawan dalam memahami suatu pengetahuan praktis ada penerapannya guna meningkatkan ketrampilan, kecakapan dan sikap yang diperlukan organisasi dalam mencapai tujuan yang juga disesuaikan dengan tuntutan pekerjaan akan diemban oleh seseorang karyawan. Dampak dari peningkatan kualitas manusia adalah manusia menjadi lebih menguasai pekerjaannya sehingga dapat meningkatkan kinerja. 
Hubungan Disiplin Kerja Terhadap Kinerja. Menurut Budi Setiyawan dan Waridin (2006) dan Aritonang (2005) menyatakan bahwa disiplin kerja karyawan bagian dari faktor kinerja. Disiplin kerja harus dimiliki setiap karyawan dan harus dibudayakan di kalangan karyawan agar bisa mendukung tercapainya tujuan organisasi karena merupakan wujud dari kepatuhan terhadap aturan kerja dan juga sebagai tanggung jawab diri terhadap perusahaan. Pelaksanaan disiplin dengan dilandasi kesadaran dan keinsyafan akan terciptanya suatu kondisi yang harmonis antara keinginan dan kenyataan. Untuk menciptakan kondisi yang harmonis tersebut terlebih dahulu harus diwujudkan keselarasan antara kewajiban dan hak karyawan. Sehingga dapat disimpulkan bahwa disiplin merupakan sikap kesetiaan dan ketaatan seseorang atau sekelompok orang terhadap peraturan-peraturan baik tertulis maupun tidak tertulis, yang tercermin dalam bentuk tingkah laku dan perbuatan. Hal demikian membuktikan bila kedisiplinan karyawan memiliki hubungan terhadap kinerja karyawan.

Hipotesis. Dari rumusan masalah, tujuan penelitian dan landasan teori maka dapat dimunculkan hipotesis sebagai berikut :

H1 : Di duga ada pengaruh positif dan signifikan antara pelatihan kerja terhadap kinerja karyawan CV. Surya Kencana Food Jombang,

H2 : Di duga ada pengaruh positif dan signifikan antara disiplin kerja terhadap kinerja karyawan CV. Surya Kencana Food Jombang,

Rancangan Penelitian. Penelitian ini dilakukan di CV. Kencana Food Jombang untuk menganalisis apakah pelatihan dan disiplin kerja berpengaruh terhadap kinerja karyawan dan ingin mengetahui sejauh mana pelatihan dan disiplin kerja berpengaruh terhadap kinerja karyawan di CV. Kencana Food Jombang. Rancangan penelituan ini merupakan penelitian eksplanasi (explanatory research), menurut Singarimbun dan Effendi (2006), penelitian eksplanasi (explanatory research) adalah penelitian yang menjelaskan hubungan antara variabel-variabel penelitian melalui pengujian hipotesis.

\section{METODE}

Adapun metode analisis data menggunakan analisis regresi berganda yang digunakan untuk mengetahui pengaruh pelatihan (X1) dan disiplin kerja (X2) terhadap kinerja karyawan (Y). Persamaan regresi berganda tersebut menggunakan rumus (Supiyan, 2007)

$$
\mathrm{KK}=\mathrm{a}+\mathrm{b} 1 \mathrm{PK}+\mathrm{b} 2 \mathrm{DK}+\mathrm{e}
$$

Keterangan : KK = Kinerja karyawan; $\mathrm{a}=$ Konstanta; $\mathrm{b} 1=$ Koefisien regresi pelatihan; b2 = Koefisien regresi disiplin kerja; PK = Pelatihan Kerja; DK = Disiplin kerja; e = Standar error

Uji t atau Uji Parsial. Pertama. Membuat formulasi hipotesis. Artinya ada pengaruh yang signiikan dari variabel independen (X) terhadap variabel dependen (2) Menentukan level signifikansi dengan menggunakan $\mathrm{t}$ - tabel; (3) Mengambil keputusan

- Jika t sig $\leq \alpha=0,05$, maka hipotesis diterima

- Jika t sig $\geq \alpha=0,05$, maka hipotesis ditolak 
Populasi dan Sampel. Populasi adalah keseluruhan subjek penelitian (Arikunto, 1996 : 102). Adapun populasi dalam penelitian ini adalah seluruh karyawan bagian produksi sift A, sift B, sift C pada CV. Surya Kencana Jombang yang berjumlah 280 orang.

Metode pengambilan sampel menggunakan Simple Random Sampling. Perhitungan sampel dalam perhitungan ini menggunakan rumus Slovin diambil dari buku Sugiono (2001). Metode pengambilan sampel menggunakan Simple Random Sampling. Perhitungan sampel dalam perhitungan ini menggunakan rumus Slovin diambil dari buku Sugiono (2001)

$$
\mathrm{n}=\frac{\mathrm{N}}{1+\mathrm{Ne}^{2}}
$$

Dimana : $\mathrm{N}=$ Ukuran Populasi; $\mathrm{n}=$ Ukuran Sampel; $\mathrm{e}=$ persen kelonggaran ketidaktelitian karena kesalhan pengambilan sampel yang masih dapat di tolerir atau inginkan (10\%)

Besarnya populasi di ketahui sebesar 280 karyawan. Jadi besar jumlah sampel yang digunakan adalah:

$$
\begin{aligned}
& \mathrm{n}=\frac{\mathrm{N}}{1+\mathrm{Ne}^{2}} \\
& =\frac{280}{1+280(0,01)} \\
& =\frac{280}{1+2,8} \\
& =3,8 \frac{280}{} \\
& =73,68=74
\end{aligned}
$$

Dari analisis perhitungan di dapat hasil sebesar 73,68 yang apabila di bulatkan maka jumlah sampel dalam penelitian ini adalah 74 karyawan.

\section{HASIL DAN PEMBAHASAN}

Uji Validitas. Uji validitas dilakukan untuk menguji apakah suatu angket layak digunakan sebagai instrumen penelitian. Perhitungan uji validitas menggunakan bantuan SPSS versi 16,0. Bila hasil uji kemaknaan $\mathrm{r}$ menunjukkan $\mathrm{r}$-hitung $>\mathrm{r}$-tabel product moment, dinyatakan valid (Riduwan, Rusyana dan Enas, 2011). ). Uji coba yang disebarkan pada 30 responden yaitu CV. Surya Kencana Food Jombang

Berdasarkan data dari Tabel 1 menunjukkan semua item pernyataan pelatihan kerja (X1), Disiplin Kerja (X2) dan Kinerja Karyawan (Y) mempunyai nilai korelasi (r) lebih besar dari $\mathrm{r}$ tabel. Dengan demikian berarti bahwa semua item pertanyaan dinyatakan valid untuk pengujian selanjutnya.

Uji Reliabilitas. Uji Reliabilitas ini diterapkan untuk mengetahui responden telah menjawab pertanyaan - pertanyaan secara konsisten atau tidak, sehingga kesungguhan jawabannya dapat dipercaya. Untuk menguji reliabilitas instrumen penelitian ini digunakan formula Cronbach Alpha (Sugiyono, 2007). Suatu konstruk atau variabel dikatakan reliabel jika memberikan nilai Croanbach Alpha > 0,6 (Arikunto, 2006), maka dapat dikatakan bahwa instrumen yang digunakan tersebut reliabel. 
Tabel 1. Hasil Uji Validitas

\begin{tabular}{|c|c|c|c|c|}
\hline \multirow[t]{2}{*}{ Variabel } & \multirow[t]{2}{*}{ Nomer Pernyataan } & \multicolumn{2}{|c|}{ Validitas } & \multirow[t]{2}{*}{ Keputusan } \\
\hline & & Korelasi (r) & $\mathrm{r}$ tabel & \\
\hline \multirow{11}{*}{$\begin{array}{c}\text { Pelatihan } \\
\text { Kerja } \\
\left(\mathrm{X}_{1}\right)\end{array}$} & $\mathrm{X}_{1.1}$ & 0,821 & 0,229 & Valid \\
\hline & $\mathrm{X}_{1.2}$ & 0,811 & 0,229 & Valid \\
\hline & $\mathrm{X}_{1.3}$ & 0,819 & 0,229 & Valid \\
\hline & $\mathrm{X}_{1.4}$ & 0,723 & 0,229 & Valid \\
\hline & $\mathrm{X}_{1.5}$ & 0,823 & 0,229 & Valid \\
\hline & $\mathrm{X}_{1.6}$ & 0,599 & 0,229 & Valid \\
\hline & $\mathrm{X}_{1.7}$ & 0,728 & 0,229 & Valid \\
\hline & $\mathrm{X}_{1.8}$ & 0,815 & 0,229 & Valid \\
\hline & $\mathrm{X}_{1.9}$ & 0,848 & 0,229 & Valid \\
\hline & $\mathrm{X}_{1.10}$ & 0,755 & 0,229 & Valid \\
\hline & $\mathrm{X}_{2.1}$ & 0,585 & 0,229 & Valid \\
\hline \multirow{7}{*}{$\begin{array}{c}\text { Disiplin } \\
\text { Kerja } \\
\left(\mathrm{X}_{2}\right)\end{array}$} & $\mathrm{X}_{2.2}$ & 0,718 & 0,229 & Valid \\
\hline & $\mathrm{X}_{2.3}$ & 0,736 & 0,229 & Valid \\
\hline & $\mathrm{X}_{2.4}$ & 0,756 & 0,229 & Valid \\
\hline & $\mathrm{X}_{2.5}$ & 0,697 & 0,229 & Valid \\
\hline & $\mathrm{X}_{2.6}$ & 0,745 & 0,229 & Valid \\
\hline & $\mathrm{X}_{2.7}$ & 0,708 & 0,229 & Valid \\
\hline & $\mathrm{X}_{2.8}$ & 0,795 & 0,229 & Valid \\
\hline \multirow{6}{*}{$\begin{array}{l}\text { Kinerja } \\
(\mathrm{Y})\end{array}$} & $\mathrm{Y}_{1}$ & 0,722 & 0,229 & Valid \\
\hline & $\mathrm{Y}_{2}$ & 0,864 & 0,229 & Valid \\
\hline & $Y_{3}$ & 0,897 & 0,229 & Valid \\
\hline & $Y_{4}$ & 0,808 & 0,229 & Valid \\
\hline & $Y_{5}$ & 0,828 & 0,229 & Valid \\
\hline & $Y_{6}$ & 0,903 & 0,229 & Valid \\
\hline
\end{tabular}

Sumber: Data primer diolah, 2015

Tabel 2. Hasil Uji Reliabilitas

\begin{tabular}{cccc}
\hline Variabel & \multicolumn{2}{c}{ Reliabilitas } & Keterangan \\
\cline { 2 - 3 } & Nilai Crombach & Angka & \\
\hline Plpha & Kritik & \\
Disiplinan Kerja $\left(\mathrm{X}_{1}\right)$ & 0,918 & 0,6 & Reliabel \\
Kinerja Karyawan $\left(\mathrm{X}_{2}\right)$ & 0,866 & 0,6 & Reliabel \\
\hline
\end{tabular}

Sumber: Data primer diolah, 2015

Berdasarkan Tabel 2 menunjukkan semua item pernyataan pelatihan kerja (X1), Disiplin Kerja (X2) dan Kinerja Karyawan (Y) memiliki koefisien alpha lebih besar 0,6, sehingga semua pernyataan dinyatakan reliabel untuk pengujian selanjutnya.

Analisis Deskripsi. Tabel dibawah ini menunjukkan hasil rekapitulasi jawaban responden terhadap masing-masing pernyataan, dengan skala pengukuran satu sampai lima dengan interpretasi skor sebagai berikut:

Variabel Pelatihan Kerja (PK) 
Tabel 3. Frekuensi jawaban responden variabel pelatihan kerja

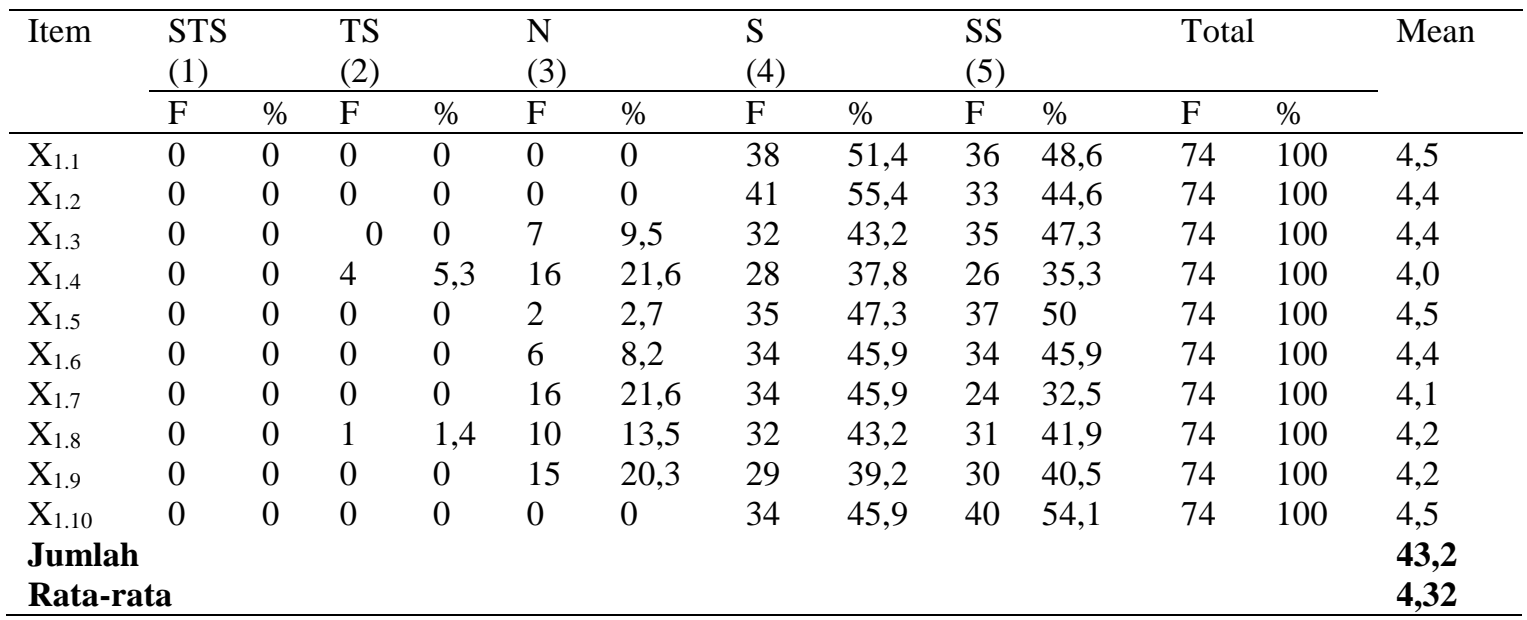

Sumber : Data primer diolah, 2015

Rata - rata yang paling rendah terdapat pada indikator metode pelatihan adalah 4,0 sedangkan rata - rata yang paling tinggi terdapat pada indikator materi yang dibutuhkan adalah 4,5. Hal ini menunjukkan bahwa jumlah jawaban responden adalah 43,2 dan ratarata jawaban dari responden pada variabel pelatihan yaitu 4,32.Hal ini dapat ditunjukkan dengan nilai jumlah indikator yang diperoleh paling tinggi pada variabel pelatihan kerja berada pada range ke lima adalah Sangat Tinggi

\section{Variabel Disiplin Kerja (DP)}

Tabel 4. Frekuensi jawaban responden variabel disiplin kerja

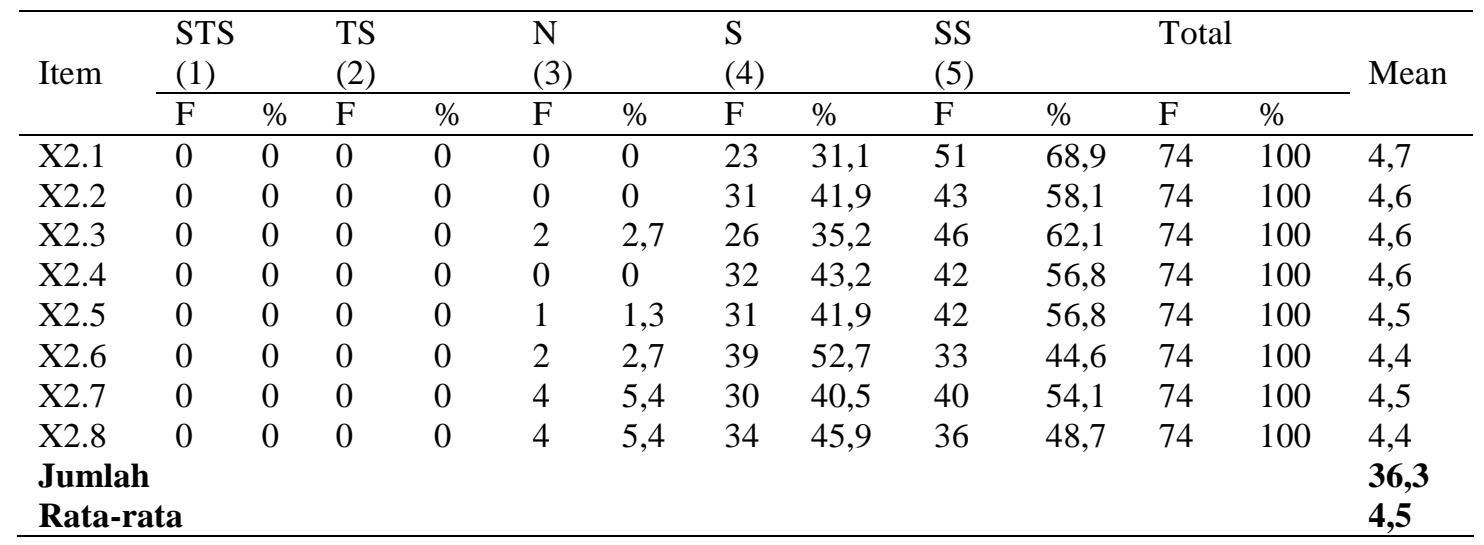

Sumber : Data primer diolah, 2015

Rata - rata yang paling rendah terdapat pada indikator tanggungjawab yang tinggi adalah 4,4 sedangkan rata - rata yang paling tinggi terdapat pada indikator ketepatan waktu adalah 4,6. Hal ini menunjukkan bahwa jumlah jawaban responden adalah 36,3 dan ratarata jawaban dari responden pada variabel pelatihan yaitu 4,5.Hal ini dapat ditunjukkan dengan nilai jumlah indikator yang diperoleh paling tinggi pada variabel pelatihan kerja berada pada range ke lima adalah Sangat Tinggi. 
Variabel Kinerja Karyawan (KK)

Tabel 5. Frekuensi jawaban responden variabel kinerja karyawan

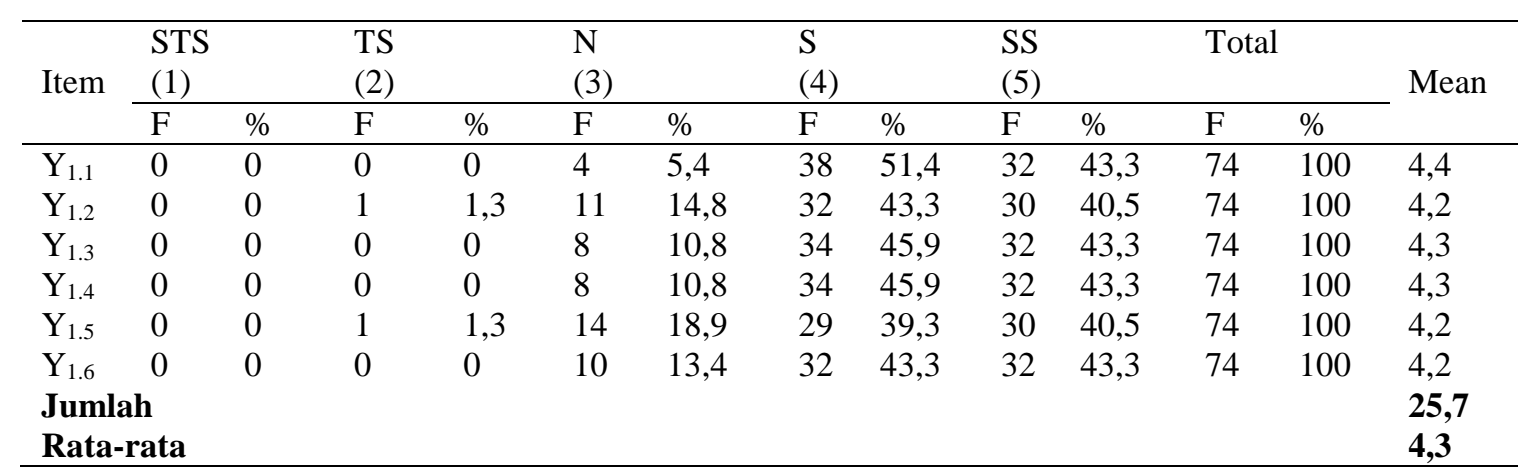

Sumber : Data primer diolah, 2015

Rata - rata yang paling rendah terdapat pada indikator kualitas adalah 4,2 sedangkan rata rata yang paling tinggi terdapat pada indikator kuantitas adalah 4,3. Hal ini menunjukkan bahwa jumlah jawaban responden adalah 25,7 dan rata - rata jawaban dari responden pada variabel pelatihan yaitu 4,3.Hal ini dapat ditunjukkan dengan nilai jumlah indikator yang diperoleh paling tinggi pada variabel pelatihan kerja berada pada range ke lima adalah Sangat Tinggi.

\section{Uji Asumsi Klasik. Hasil Uji Normalitas}

\section{Normal P-P Plot of Regression Standardized Residual}

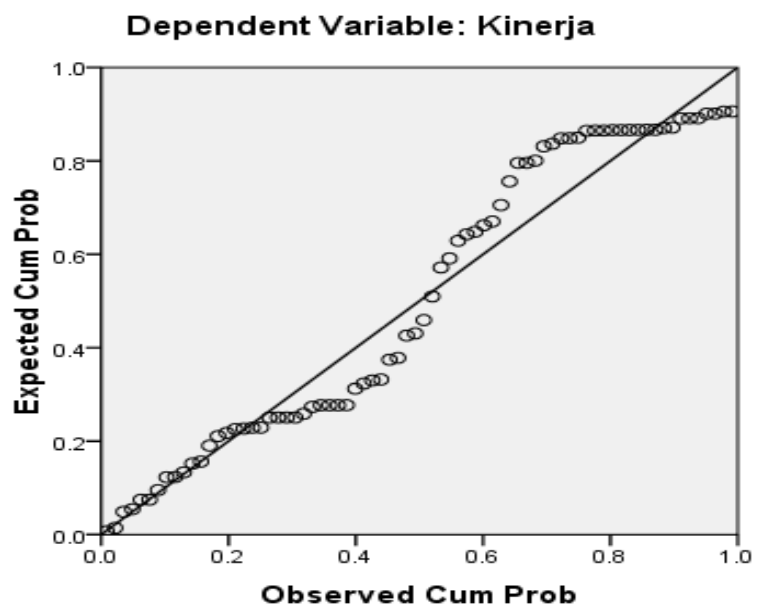

Gambar 1. NormalP-Plotof Regression Residual Sumber : output SPSS, 2015

Berdasarkan Gambar 1 terlihat bahwa semua data berdistribusi secara normal, sebaran data berada disekitar garis diagonal. 


\section{Uji Asumsi Multikolinieritas}

Tabel 6.Uji Multikolinearitas

\begin{tabular}{llll}
\hline No & Variabel & Tolerance & Nilai VIF \\
\hline 1. & Pelatihan Kerja & 0,673 & 1,460 \\
2. & Disiplin Kerja & 0,673 & 1,460 \\
\hline
\end{tabular}

Sumber : Data primer diolah, 2015

Dari Tabel 6 tersebut menunjukkan bahwa nilai VIF semua variabel bebas dalam penelitian ini lebih kecil dari 10 dan nilai toleransi semua variabel bebas lebih dari $10 \%$ sehingga disimpulkan tidak terjadi korelasi antar variabel bebas, dengan demikian dapat disimpulkan bahwa tidak terdapat gejala multikolinearitas antar variable bebas dalam model regresi

\section{Uji Asumsi Heterokedastisitas}

\section{Scatterplot}

\section{Dependent Variable: Kinerja Karyawan}

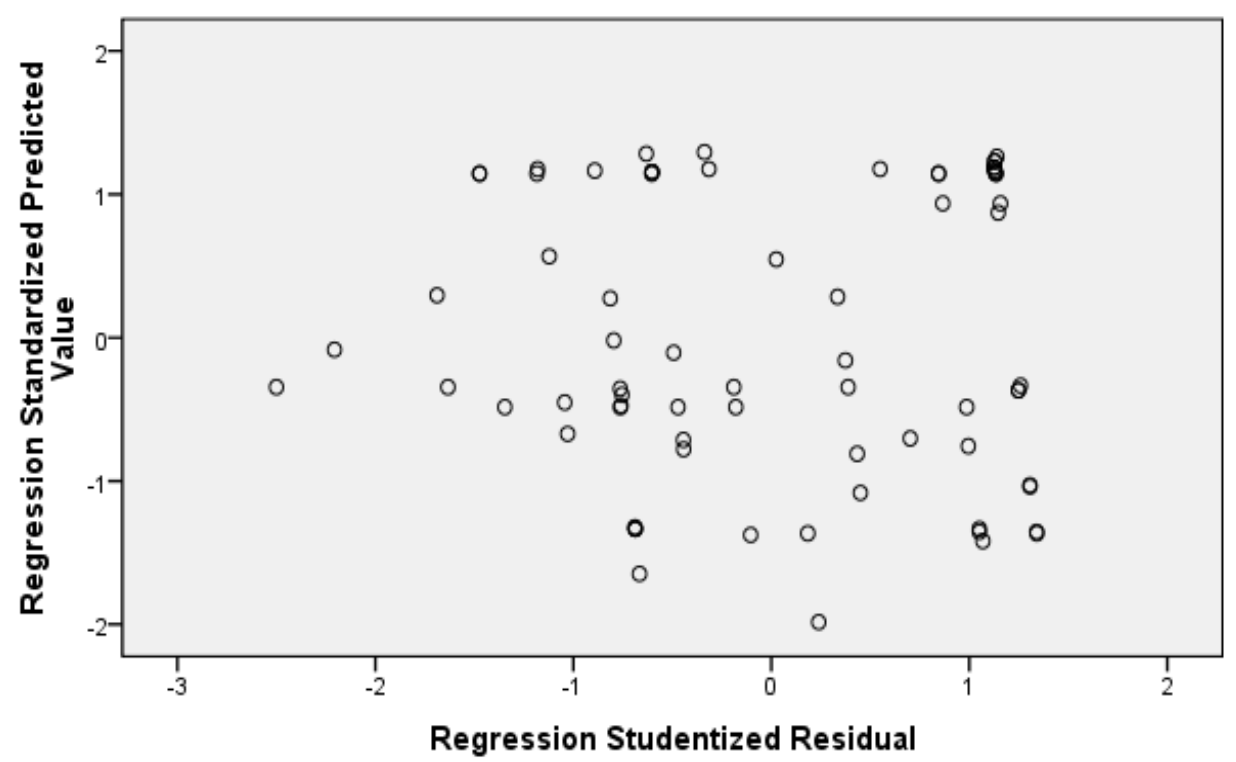

Gambar 2 . Hasil Pengujian Heterokedastisitas

Sumber:: outputSPSS, 2015

Berdasarkan gambar 2 menunjukkan bahwa tidak terdapat pola yang jelas maka tidak terjadi heterokedastisitas sehingga model regresi tersebut layak digunakan. 


\section{Regresi Linear Berganda}

Tabel 7. Hasil Regresi Linear Berganda

\begin{tabular}{|c|c|c|c|c|c|c|c|c|}
\hline \multicolumn{9}{|c|}{ Coefficients ${ }^{a}$} \\
\hline & & \multicolumn{2}{|c|}{$\begin{array}{l}\text { Unstandardized } \\
\text { Coefficients }\end{array}$} & \multirow{2}{*}{$\begin{array}{l}\text { Standardized } \\
\text { Coefficients } \\
\text { Beta }\end{array}$} & \multirow[b]{2}{*}{$\mathrm{t}$} & \multirow[b]{2}{*}{ Sig. } & \multicolumn{2}{|c|}{$\begin{array}{l}\text { Collinearity } \\
\text { Statistics }\end{array}$} \\
\hline \multicolumn{2}{|c|}{ Model } & $\mathrm{B}$ & Std. Error & & & & Tolerance & VIF \\
\hline \multirow[t]{3}{*}{1} & (Constant) & 5.103 & 1.038 & & 3.465 & .000 & & \\
\hline & pelatihan kerja & .212 & .082 & .217 & 2.148 & .026 & .673 & 1.460 \\
\hline & disiplin kerja & .194 & .048 & .382 & 2.243 & .040 & .673 & 1.460 \\
\hline
\end{tabular}

Sumber : Data primer diolah, 2015

Dari tabel 7. maka dapat dituliskan bahwa persamaan regresi berganda untuk model yang peneliti gunakan adalah sebagai berikut :

$$
\begin{aligned}
& \mathrm{KK}=\mathrm{a}+\mathrm{bPK}+\mathrm{bDK}+\mathrm{e} \\
& \mathrm{KK}=5.103+0,212(\mathrm{PK})+0,194(\mathrm{DK})+\mathrm{e}
\end{aligned}
$$

Persamaan regresi di atas mengandung arti sebagai berikut :

Koefisien regresi menunjukkan terdapat pengaruh yang positif dan signifikan yang berarti semakin tinggi tingkat pelatihan kerja dan disiplin kerja, maka berpengaruh pada semakin tingginya kinerja karyawan.

\section{Pengujian Hipotesis dengan uji t}

Tabel 8. Hasil Uji t

\begin{tabular}{lllll}
\hline No & Variabel & & T hitung & Signifikan \\
\hline 1 & Pelatihan & Kerja & 2,148 & 0,026 \\
& $\left(\mathrm{X}_{1}\right)$ & & & \\
2 & $\begin{array}{l}\text { Disiplin } \\
\left(\mathrm{X}_{2}\right)\end{array}$ & Kerja & 2,243 & 0,040 \\
& & &
\end{tabular}

Sumber : output SPSS, 2015

Pengujian Hipotesis Pertama (H1). Variabel X1 (Pelatihan Kerja) memiliki statistik uji t hitung sebesar 2,148 dan signifikansi sebesar 0,026, karena nilai $\mathrm{t}_{\text {sig }}=0,026<\alpha=0,05$, dengan demikian dapat dinyatakan bahwa pelatihan kerja berpengaruh terhadap kinerja karyawan pada CV. Surya Kencana Food Jombang.

Pengujian Hipotesis Kedua (H2). Variabel X2 (Disiplin Kerja) memiliki statistik uji t hitung sebesar 2,243 dan signifikani sebesar 0,040, karena nilai $\mathrm{t}_{\text {sig }}=0,040<\alpha=0,05$, dengan demikian dapat dinyatakan bahwa disiplin kerja berpengaruh terhadap kinerja karyawan pada CV. Surya Kencana Food Jombang. 
Pengaruh pelatihan kerja terhadap kinerja karyawan. Berdasarkan hasil penelitian menggambarkan bahwa pelatihan berperan dalam meningkatkan kinerja karyawan pada CV. Surya Kencana Food Jombang. Hal ini berarti bahwa apabila pelatihan yang diberikan kepada karyawan sesuai oleh pihak perusahaan maka kinerja karyawan akan meningkat, sesuai dengan tanggapan responden mengenai pelatihan yang mencakup 1) Materi yang dibutuhkan, Materi yang disusun dari estimasi kebutuhan tujuan latihan, kebutuhan untuk pengajaran keahlian khusus, 2) Metode pelatihan, yang digunakan melalui metode-metode pelatihan yang secara sistematik, 3) Prinsip pembelajaran, Materi yang digunakan berupa pelatihan yang diberikan, 4) Ketepatan dan kesesuain fasilitas, fasilitas sangat menunjang bagi terlaksananya program pelatihan, 5) Kemampuan peserta pelatihan.

Pelatihan merupakan suatu proses pengembangan sumber daya manusia untuk meningkatkan kemampuan intelegensi yang berdampak pada peningkatan kualitas manusia itu sendiri. Pelatihan adalah suatu kegiatan untuk memperbaiki kemampuan kerja karyawan dalam memahami suatu pengetahuan praktis dan penerapannya guna meningkatkan keterampilan, kecakapan dan sikap yang diperlukan organisasi dalam mencapai tujuan yang juga di sesuaikan dengan tuntutan pekerjaan yang akan di emban oleh seorang karyawan. Dampak dari peningkatan kualitas manusia adalah manusia menjadi lebih menguasai pekerjaannya sehingga dapat meningkatkan kinerja. Hasil penelitian tersebut mendukung teori Simamora (2001) yang menyatakan bahwa salah satu tujuan pelatihan adalah memberikan keuntungan kedua belah pihak yaitu pihak perusahaan dan karyawan sendiri. Bagi karyawan, dengan mengikuti latihan akan lebih matang dalam kepribadian intelektual dan keterampilan, memiliki pengaruh terhadap kinerja.

Pengaruh disiplin kerja terhadap kinerja karyawan. Berdasarkan hasil penelitian disiplin kerja yang memiliki pengaruh signifikan terhadap kinerja karyawan pada CV. Surya Kencana Food Jombang. Karena tanpa adanya disiplin kerja, maka segala kegiatan yang akan dilakukan mendatangkan hasil yang kurang memuaskan dan tidak sesuai dengan harapan. Hal ini dapat mengakibatkan kurangnya pencapaian sasaran perusahaan serta dapat juga menghambat jalannya program organisasi yang di buat. (Maslan Banni, Nilam Korompot, Robiansyah, 2008) tujuan dari disiplin kerja agar dapat melaksanakan pekerjaan dengan sebaik - baiknya serta maupun memberikan pelayanan yang maksimum kepada pihak tertentu yang berkepentingan dengan perusahaan. Dengan demikian hipotesis yang telah dipaparkan sebelumnya telah terbukti bahwa terdapat pengaruh yang signifikan secara parsial antara pelatihan kerja dan disiplin kerja terhadap kinerja karyawan pada CV. Surya Kencana Food Jombang.

\section{PENUTUP}

Simpulan. Dari hasil penelitian mengenai Pengaruh Pelatihan Kerja dan Disiplin Kerja Terhadap Kinerja Karyawan Pada CV. Surya Kencana Food Jombang, dapat disimpulakan sebagai berikut: (1) Variabel pelatihan kerja berpengaruh positif dan signifikan terhadap kinerja karyawan pada CV. Surya Kencana Food Jombang; (2) Variabel disiplin kerja berpengaruh positif dan signifikan terhadap kinerja karyawan pada CV. Surya Kencana Food Jombang.

Saran. Berdasarkan kesimpulan di atas, maka dapat dikemukakan beberapa saran yang kiranya dapat bermanfaat bagi perusahaan antara lain: Pertama Mengenai pelatihan kerja, perusahaan pada dasarnya sudah baik dalam memberikan pelatihan kepada karyawan. Jadi, 
Perusahaan tidak perlu melakukan perubahan besar dalam hal pelatihan kerja, hanya membutuhkan perbaikan dan peningkatan dalam beberapa faktor yang mempengaruhi pelatihan kerja baik secara langsung maupun tidak langsung, hal tersebut dapat dilakukan dengan memperbaiki metode yang digunakan dalam pelatihan kerja, memperbaiki kualitas secara pelatihan kerja dan lebih menyesuaikan pelatihan kerja dengan kemampuan karyawan produksi sesuai dengan pelatihan yang dibutuhkan. Kedua. Disiplin Kerja memiliki peran terhadap peningkatan kinerja karyawan. Oleh sebab itu pihak perusahaan perlu meningkatkan manajemen yang baik terutama tentang kinerja sesuai dengan target yang ditentukan oleh perusahaan. Namun selain meningkatkan menajemen yang baik, ada baiknya perusahaan memberikan reward bagi karyawan yang tiap hari disiplin kerjanya mengalami peningkatan, sehingga perusahaan dan karyawan sama-sama memberikan keuntungan satu sama lain. Ketiga. Bagi CV. Surya Kencana Food Jombang perlu memperhatikan metode pelatihan yang diberikan kepada karyawan serta pemberian sanksi - sanksi jika ada kesalahan yang diperbuat oleh karyawan dan perlu perhatian khusus terkait kualitas pekerjaan.

\section{DAFTAR RUJUKAN}

Ambarita R, (2012) Anggap Karyawan Aset, Kunci Sukses Perusahaan. http://www.kabarbisnis.com/read/2833544.

Amran (2009) Pengaruh Disiplin Kerja Terhadap Kinerja Pegawai Kantor Departemen Sosial Kabupaten Gorontalo" Jurnal Ichsan Gorontalo, 4 (2), 2397-2413

Agusta, Leonando, (2013) Pengaruh Pelatihan Dan Motivasi Kerja Terhadap Kinerja Karyawan CV. Haragon Surabaya.

Dessler G, (2009) Manajemen Sumber Daya Manusia, Jakarta : Index.

Dharma, Agus, (2009). Manajemen Perilaku Organisasi, edisi keempat, Jakarta : Erlangga.

Ernawati, Marjono (2007 ) Pengaruh Supervisi danDisiplin Kerja Terhadap Kinerja Guru. Jurnal Manajemen Sumber Daya Manusia, Volume : 2 Tahun 2007

Ghozali, Imam, (2007) Aplikasi Analisis Multivariate Dengan Program SPSS, Edisi Dua, Badan Penerbit Universitas Diponegoro.

Hasibuan, (2007) Manajemen Sumber Daya Manusia, cetakan kesembilan, Jakarta : PT. Bumi Aksara.

Hestisani, Hendri, (2014). Pengaruh Motivasi Berpengaruh Dan Disipiln Kerja Terhadap Kinerja Pegawai Badan Kepegawaian Daerah Kabupaten Buleleng.

Idrees, Zahra, (2015) Effect of salary, Training and motivation on job performance of employees.

Mangkunegara, Anwar Prabu, (2006) Evaluasi Kinerja SDM, Bandung, Penerbit : PT. Refika Aditama.

Maslan Banni, Nilam Korompot \& Robiansyah, (2008) Pengaruh Disiplin Dan Motivasi terhadap kinerja karyawan Pegawai Pada PLN (Persero) Wilayah Kalimantan Timur Area Samarinda.

Melmambesersy, Moses (2012) Pengaruh Pendidikan Pelatihan Dan Pengalaman Kerja Terhadap Produktivitas Kerja Pegawai Dinas Pertambangan Dan Energi Provinsi Papua, Jurnal Bisnis Dan Manajemen.

Ni Kadek Dwi Rahayuni (2009) Pengaruh Pelatihan Dan Pengalaman Kerja Terhadap Kemampuan Kerja Serta Dampaknya Terhadap Prestasi Kerja Karyawan Pada Hotel Sanur Beach Bali, Jurnal Bisnis Dan Manajemen 
Noe Raymond A, (2010) Manajemen Sumber Daya Manusia Mencapai Keunggulan Bersaing, Jakarta: Salemba Empat.

Riduwan, Rusyana, Adun dan Enas, (2011) Cara Mudah Belajar SPSS 17,0 dan Aplikasi Statistik Penelitian, Bandung: Penerbit CV. Alfabeta.

Rivai, Veithzal, (2004) Manajemen Sumber Daya Manusia untuk perusahaan, Jakarta: PT Rajagrafindo, Persada.

Sinambela, Lijan Poltak, (2012). Kinerja Pegawai Yogyakarta : Graha ilmu.

Sugiyono, (2012). Metode Penelitian Kuantitatif Kualitatif Dan R\&D, Bandung : Alfabeta. Supriyanto, (2007) "Pengaruh Disiplin Kerja, Lingkungan Kerja dan Motivasi Kerja Terhadap Kinerja Karyawan", Jurnal Manajemen Sumber Daya Manusia, 2 (1) Desember 2007

Umar, Husein, (2002) Sumber Daya Manusia Dalam Organisasi, Jakarta : PT. Gramedia Pustaka Utama.

Veithzal Rivai, (2004) Manajemen Sumber Daya Manusia Untuk Perusahaan, Jakarta: PT. Raja Grafindo Persarda 